\title{
Historical Papers
}

Communications historiques

\section{Bishop Laflèche and the Mandement of 1896}

\section{P. E. Crunican}

Volume 4, numéro 1, 1969

Toronto 1969

URI : https://id.erudit.org/iderudit/030707ar

DOI : https://doi.org/10.7202/030707ar

Aller au sommaire du numéro

\section{Éditeur(s)}

The Canadian Historical Association/La Société historique du Canada

ISSN

0068-8878 (imprimé)

1712-9109 (numérique)

Découvrir la revue

Citer cet article

Crunican, P. E. (1969). Bishop Laflèche and the Mandement of 1896. Historical Papers / Communications historiques, 4(1), 52-61.

https://doi.org/10.7202/030707ar

All rights reserved @ The Canadian Historical Association/La Société historique du Canada,1969
Ce document est protégé par la loi sur le droit d'auteur. L'utilisation des services d'Érudit (y compris la reproduction) est assujettie à sa politique d'utilisation que vous pouvez consulter en ligne.

https://apropos.erudit.org/fr/usagers/politique-dutilisation/ 


\title{
BISHOP LAFLECHE AND THE MANDEMENT OF 1896
}

\author{
P. E. Crunican \\ King's College, University of Western Ontario
}

In the story of domination by cleric in French Canadian society during the latter half of the nineteenth century, two names stand out : Ignace Bourget, Bishop of Montreal (1841-1876), and Louis François Laflèche, Bishop of Trois-Rivières (1867-1898). Much remains to be done in explaining both the connecting links and the differences between these two men. On many levels of comparison, Laflèche emerges as the more intelligent and admirable of the two figures. Yet where Bourget, despite ludicrous episodes such as the Guibord case, was by and large successful in imposing his pattern, Laflèche for the most part failed. A good deal of the variance in success can be attributed to the change from the era of Pius IX to that of Leo XIII. But the atmosphere was changing in Quebec as well.

This paper will study briefly one of the last flamboyant stands of the Bourget-Laflèche school, the sermon by the Bishop of TroisRivières which followed the publication on May 17, 1896, of the election mandement signed by all the bishops of Quebec. That pastoral letter attempted to oblige Quebec Roman Catholics in the forthcoming federal election to vote only for those candidates pledged to support legislation to restore Catholic school privileges in Manitoba. Even as it stood, the mandement was the most formal and solemn attempt by Canadian churchmen to influence directly the Canadian political process. Yet the Laflèche sermon went far beyond the mandement in its explicit condemnation of the Liberals and, in particular, of Wilfrid Laurier.

In attempting to assess the significance of the Laflèche stand, it is, I believe, crucial to examine two sequences of events : the period leading up to the drafting of the mandement, and the reaction to Laflèche's dramatic extention of the general pastoral letter. In May of 1895, Laflèche, himself a former missionary in the Red River settlement, had spent considerable effort in order to assure that the newly consecrated successor to Archbishop Taché of St. Boniface, Adélard Langevin, would not accept any compromise short of full restoration of the pre-1890 Catholic schools in Manitoba. ${ }^{1}$ Following Manitoba's courteous but adamant refusal of June 1895 to

1 Archives Archiépiscopales de Saint-Boniface (hereafter referred to as AASB), Laflèche to Langevin, May 28, 1895. 
comply with the federal remedial order issued three months earlier, the seventy-eight year old prelate bombarded Cabinet Ministers, Senators and Members of Parliament with letters demanding remedial legislation without delay. ${ }^{2}$ The July 1895 decision of Auguste Réal Angers to resign from the cabinet in protest against conservative failure to introduce a remedial bill, can be seen partly as a result of a Laflèche letter demanding some unmistakable protest against the endless delays of justice for the Manitoba minority. "On pourrait succomber dans cette tâche que le fanatisme rend à la vérité difficile," Laflèche told Angers, "mais au moins, s'il le fallait, que l'on ne soit pas dupé et que l'on tombe avec honneur comme les Rois qui reçoivent un coup d'épée en pleine poitrine et se relèvent toujours, et non point comme ceux qui tombent d'un coup de pied ailleurs, et ne se relèvent jamais, ainsi que le disait Louis Veuillot." 3 When Father Albert Lacombe, chief Ottawa lobbyist for Archbishop Langevin, drafted his celebrated threatening letter to Wilfrid Laurier in January 1896, it was clear that the chief inspiration behind the challenge was Bishop Laflèche. ${ }^{4}$ The Trois-Rivières prelate heartily endorsed the attempt by Bishop Labrecque of Chicoutimi to swing a January byelection to the Conservatives by means of a pastoral letter. ${ }^{5}$ Finally, it was only through strong opposition from Archbishop Bégin, Administrator of Quebec, that Laflèche was persuaded not to insist on a public letter to all Catholic M.P.'s which would have attempted to oblige them to vote for the remedial bill during the debate in March and April 1896. ${ }^{6}$

Thus the lines of division among the eleven active Quebec bishops were already quite clearly drawn before their plenary meeting to decide on an election mandement. At the session held in Montreal on May 6, the group favoring an explicit support of the Conservative party as the only hope for remedial legislation was led by Langevin and Laflèche. The opposing wing, which profoundly feared overidentification with any political party, was led by Bishop Emard of Valleyfield and Archbishop Fabre of Montreal. Acting as chief conciliator between the two factions was Bégin, Metropolitan of the primatial see. Although the final draft of the mandement may be interpreted somewhat as a "least common denominator" among the episcopal views, the document adopted was in essence the one drawn up by Bégin in the wake of Emard's objections to Langevin's much more inflexible version. ${ }^{\top}$

2 See, for example, Archives Archiépiscopales de Québec (hereafter referred to as AAQ), Laflèche to Caron, June 21, 1895 .

3 AAQ, Laflèche to Angers, July 7, 1895.

4 AASB, Lacombe to Langevin, January 20, 1896.

5 AAQ, Laflèche to Bégin, February $6,1896$.

6 AAO, Bégin to Laflèche, February 27, 1896.

7 AAQ, Bégin to Marois, May 6, 1896. 
Prior to the Montreal meeting, however, Laflèche had promised something much stronger. In a self-revealing exclamation to Langevin following the speeches by Laurier and Sir Charles Tupper during the remedial bill debate, the old bishop stated that he was not at all disappointed by the positions adopted by the two party leaders. "C'est un duel à mort, il faut vaincre ou mourir l" Laflèche proclaimed. "Tant mieux! J'aime les situations claires et précises, chaudes ou froides, parce que l'eau tiède provoque le vomissement $1 " 8$ Less than a week before the mandement conference, Laflèche told his friend, Vicar General Marois of Quebec, that, whatever the other bishops might do, he would speak out against the Liberals and Laurier in particular, "de manière à ne pas mériter du Souverain Juge qui m'appellera bientôt à son tribunal suprême le reproche de chien muet incapable d'aboyer aux approches du loup." $\theta$ Thus, despite the injunction placed on the curés to read the mandement without commentary, the elderly prelate, whose life had been dominated by confrontation, refused to swerve from consistency with his past. At High Mass on May 17 in the cathedral of Trois-Rivières, Laflèche appeared in the pulpit with the mandement in one hand and a copy of Hansard in the other. Following a scathing denunciation of neutral schools as the worst possible educational formula, the bishop, without mentioning Laurier by name, attacked the position enunciated by the Liberal leader in his March 3 speech in Parliament. Laurier's insistence that he would formulate policy on remedialism, as on all public questions, "non pas au point de vue du catholicisme, non pas au point de vue du protestantisme, mais ... pour des motifs qui peuvent s'adresser à la conscience de tous les hommes," was held up as a classic case of "le libéralisme condamné par léglise." Since the Liberal chief, in the prelate's view, had thus explicitly taken the position of "un libéral rationaliste," Laflèche's conclusion on the current election was an open and shut case :

Dans les circonstances, un catholique ne saurait, sous peine de pécher en matière grave, voter pour un chef de parti qui a formulé aussi publiquement une pareille erreur et pour les partisans qui l'appuient dans cette erreur, tant qu'ils n'auront pas désavoué publiquement cette erreur, et pris l'engagement formel de voter pour une loi réparatrice acceptée par les évêques. 10

It should be noted that Laflèche, although he was to be provoked into making repeated anti-Laurier statements as the campaign progressed, did in fact leave a slight opening for Liberal candidates and voters to construct an arguable position even within his own narrow categories. More important, however, was the fact that Laflèche's

8 AASB, Laflèche to Langevin, March 6, 1896.

9 AAQ, Laflèche to Marois, May 1, 1896.

10 Le Trifluvien, May 20, 1896. 
spectacular extension of the general episcopal letter did not receive widespread publicity until a significant reaction to the moderate collective statement had been experienced. Although the "official" Conservative party newspapers in Quebec, such as Le Courrier du Canada and L'Événement, proclaimed the mandement to be "une approbation éclatante de la politique d'intervention à laquelle s'est lié le parti conservateur," 11 most editorials stressed its non-partisan quality. English Liberal papers, such as the Toronto Globe and the Winnipeg Tribune, could not bypass the occasion to assail the hierarchy's presumption in getting involved in the political process at all. ${ }^{12}$ The Conservative Montreal Gazette, however, like the Toronto Mail and Empire, stressed the fact that the mandement was a "very mild sort of document," which left "the Roman Catholic people's choice free between the candidates of the two parties." ${ }^{13}$ The independent Conservative La Presse of Montreal praised the high tone and impartiality of the pastoral letter, ${ }^{14}$ but it was the French Liberal papers which led the way in enthusiasm. Ernest Pacaud's L'Electeur of Quebec City was sure that the result of the mandement would be "un respect plus grand, une affection plus vive, une considération plus élevée pour la hiérarchie qui nous commande tous, conservateurs comme libéraux, dans le domaine spirituel." 15 Even Honoré Beaugrand's aggressively Rouge La Patrie ventured a rare expression of filial devotion for the Church. "Le document lancé hier est assez éloquent par lui-même que nous serons assez délicat pour ne pas le commenter," La Patrie stated. Beaugrand even indulged in righteous indignation at the reaction of disappointed Conservatives. "Il est vraiment scandaleux," the editorial ran, "d'entendre les conservateurs de certains ministériels hier aux portes des églises. 'C'est tout ce qu'on pu avoir Taillon et Angers,' disaient-ils, 'c'est ça le mandement, il est en faveur des libéraux; nous sommes flambés, etc." "16 Although much more restrained than the Liberal press, both Laurier and his chief Quebec organizer, J. Israel Tarte, expressed cautious relief at the tone and content of the bishops' letter. ${ }^{17}$

Laflèche's sermon was first printed in Le Trifluvien on Wednesday, May 20. On the following day, La Patrie gave the sermon a ten-line mention on its back page, challenging it not by an appeal to

11 L'Evénement, May 18, 1896.

12 Toronto Globe, May 18, 1896; Winnipeg Tribune, May 21, 1896. 1896.

13 Montreal Gazette, May 18, 1896; Toronto Mail and Empire, May 18,

14 La Presse, May 18, 1896.

15 L'Electeur, May 18, 1896.

16 La Patrie, May 18, 1896.

17 Public Archives of Canada (hereafter referred to as PAC), Laurier Papers, Mowat to Laurier, May 22, 1896; Willison Papers, Tarte to Willison, May 17, 1896. 
revolt nor even to reason, but to the overriding authority of the collective mandement. ${ }^{18}$ It was not until Saturday, May 23, and the beginning of the following week, that the leading newspapers of both languages began to make a major issue of the Trois-Rivières thunderbolt. Laurier's first reaction was that Laflèche's sermon might hurt the Liberals in the three ridings of Trois-Rivières diocese, but that it would not be "seriously injurious" elsewhere. The Liberal leader advised John Willison of The Globe that in Ontario "it ought to be worked to some advantage," at the same time insisting on restraint and on an appeal to reasonable English-speaking Catholics. ${ }^{10}$ Subsequent Globe comments on Laflèche's utterance were in fact relatively moderate, as was the defense of the bishop made by $L a$ Presse against La Patrie and the aggressively Protestant Montreal Witness. La Presse upheld the right of the bishop to comment on the mandement in his own diocese, but appealed more to the respect due to the age and personal esteem in which Laflèche was held than to the correctness of his doctrine. ${ }^{20}$

Extreme elements of both parties, however, were not content with such dovelike reactions. In point of fact, each faction tended to overplay its hand. Conservative organizers were not prepared to leave the sermon in any condition of obscurity. One of the most popular election leaflets became a reprint of the section of Laflèche's sermon condemning Laurier's March 3 speech. One Liberal report from Ottawa mentioned that as many as one hundred thousand such flyers had been run off at government expense at the Queen's Printers. ${ }^{21}$ So out of keeping with the general mandement was the interpretation put on the Laflèche sermon that Tarte's Le Cultivateur and Liberal speakers generally had little difficulty dismissing the contention that a vote for a Liberal would be considered a grave sin. In retaliation against Conservative extremism, however, L'Electeur launched a campaign which, like the Laflèche statement itself, backfired at least as much as it accomplished its purpose. After several preliminary editorials accusing Laflèche of finding another way to publicize opinions which he had been unable to impose on the other bishops at their Montreal meeting. ${ }^{22}$ L'Electeur began on June 1 a series of articles signed simply "Communiqué." The author strongly attacked both those who were elevating Laflèche to infallibility, and the bishop himself, going so far, ironically, as to accuse Laflèche in his own turn of "le libéralisme catholique condamné par l'Église." ${ }^{23}$ The series

La Patrie, May 21, 1896.

PAC, Willison Papers, May 25, 1896.

La Presse, May 23, 1896.

L'Electeur, June 5, 1896.

Ibid., May 26, 1896.

Ibd., June 1, 2, 4, 1896. 
culminated in a June 6 article entitled "TRAFIC HONTEUX DE LA RELIGION," which contained several direct references to the difficulties Laflèche had experienced with the Vatican in the early 1880 's, as well as to reverses which he had suffered in confrontations with Cardinal Taschereau. ${ }^{24}$

The articles brought a wave of reaction in favour of the elderly bishop, at least in protest against the vehemence of the attacks. Several of the other bishops, including those such as Moreau of St. Hyacinthe who had had long-standing differences with Laflèche, wrote sympathetic letters to their embattled dean. ${ }^{25}$ Archbishop Bégin of Quebec, who had thus far remained as much as possible out of the active picture, felt compelled to send a June 9 letter of reproof to L'Électeur. Observing "avec regret" the charges made against "un vétéran de l'épiscopat," Bégin told editor Pacaud that "comme administrateur de l'archidiocèse je ne puis m'empêcher de protester énergiquement contre l'attitude actuelle de votre journal à l'égard de Monseigneur l'Évêque des Trois-Rivières et de condamner sévèrement les articles qui y ont été publiés contre lui." Bégin insisted that unless the newspaper improved its tone, "je me verrai dans la pénible nécessité de censurer de nouveau votre journal." ${ }^{26}$ The criticism by Bégin and others was sharp enough to move Pacaud to an almost unseemly haste to disavow the authorship of the articles. "Comme Sa Grandeur," the newspaper stated on June 11, "la rédaction de L'Électeur a considéré qu'il était inopportun pour nous de critiquer le sermon de Sa Grandeur Monseigneur Laflèche, que les conservateurs ont mis en circulation comme littérature électorale." At the same time L'Electeur insisted that the articles revealed widespread clerical rejection of the Laflèche position, stating that the criticisms had been submitted "par des prêtres distingués de cette province, et que nous leur en laissons la responsabilité." 27 Pacaud vigorously upheld the same position in a letter to his personal friend Monsignor J. C. K. Laflamme, rector of the Quebec seminary, on the latter's withdrawal of his subscription because of the anti-Laflèche articles. "Si vous saviez à quelle pression il me faut résister pour tempérer les membres du clergé en sympathie avec M. Laurier !", the editor told Laflamme. "J'ai devant moi plus de cinquante lettres de prêtres me représentant qu'ils n'osent agir mais qu'ils content sur L'Électeur pour résister énergiquement à la campagne scandaleuse qui se fait en ce moment contre mes amis politiques." ${ }^{28}$

24 Ibid., June 6, 1896.

25 Archives Episcopales des Trois-Rivières, Moreau to Laflèche, June 10, 1896.

$26 \quad$ L'Electeur, June 11, 1896.

27 Ibid., June 11, 1896.

28 AAQ, Pacaud to Laflamme, n.d. 
Whatever the accuracy of Pacaud's claim of clerical support, the Quebec newspaper's attempt at retaliation against Laflèche had indeed stirred up a blacklash of sympathy. Yet sympathy did not necessarily equal imitation. It can, I believe, be persuasively demonstrated that the campaign in Quebec, even in its final weeks, cannot be pictured simply as a frontal clash between Laurier and the clergy. If Bishop Gravel provided some echo for Laflèche in the latter's former area in Nicolet, there was Monsignor Marquis of St. Célestin to provide a counterthrust. If Labrecque in Chicoutimi lamented the absence of filial respect for the church among those who supported Laurier, his Vicar General Bruno Leclerc was able to assure his friend and parishioner Charles Angers, Liberal candidate for Charlevoix, that acceptance of the mandement was all that was required. When Langevin of St. Boniface launched a series of pro-Conservative sermons in his home district south of Montreal, Archbishop Fabre felt himself obliged to ask the western prelate to desist. ${ }^{2 \theta}$ The case of Archbishop Bégin was particularly significant, since the archdiocese of Quebec enclosed a total of fifteen ridings. Traditionally grouped among those who imitated Laflèche during the campaign, Bégin, in fact, under pressure from Langevin, insisted that the vast majority of his clergy would not take political sides, going so far as to imply the probability of a Liberal victory. Despite the over-zealous statement of Vicar General Marois to the contrary, Bégin gave conditional approval to the position taken by several Liberal candidates, even to that of Henri Joly de Lotbinière, the veteran Huguenot running in Portneuf. ${ }^{30}$

In English-speaking Canada, most of the bishops expressed their approval of the mandement, although they felt it wise not to extend the document officially beyond the borders of Quebec. Only Bishop John Cameron of Antigonish adopted a stance echoing that taken by Laflèche. ${ }^{31}$ Archbishop Walsh of Toronto found himself in the position of being quoted by L'Electeur as approving a vehement antiLaflèche sermon given by one of his priests. ${ }^{32}$ Walsh denied the rumour, but a post-election letter from the author of the sermon, Fr. Minehan, to Laurier, gave a quite different slant. Minehan insisted 1896.

29 Archives Archiépiscopales de Montréal, Fabre to Langevin, May 12,

30 Evidence on the activity of the Quebec clergy during the 1896 election is reviewed at length in P. E. Crunican, "The Manitoba School Question and Canadian Federal Politics, 1890-1896: A Study in Church-State Relations," Ph.D. thesis, University of Toronto, 1968, pp. 554-570. The conclusions arrived at there differ substantially from the traditional picture presented by R. Rumilly, Mgr Laflèche et son temps (Montréal, 1938) and by many other authors.

31 J. B. Proulx, Documents pour servir à l'intelligence de la question des écoles du Manitoba, Rome, 1896, p. 115.

$32 \quad$ La Minerve, June 1, 1896. 
that, despite Walsh's reproof of his statements, the Toronto Archbishop "was not very sorry they were said. They showed that the Catholic Church in Canada was not tied to the Tory Party." 33 The Toronto diocesan paper, the Catholic Register, calmly but firmly rejected Laflèche's handling of Laurier's parliamentary statement, calling the bishop's sermon "beyond the limits of an authentic interpretation of their joint declaration," and "only the individual opinion of Mgr. Laflèche." 34

If, for purposes of analysis, Laurier versus Laflèche may be isolated during the campaign, Laurier clearly was the victor. The significance of the point, however, should not be missed. What the Liberal leader and his followers had succeeded in doing was to convince enough voters that the gap between what the bishops as a group were demanding and what the Liberals were promising, was not as wide as Laflèche, some of the curés and the Conservative campaigners had painted it. In effect, this meant that, however much the prospect of "un des nôtres" as Prime Minister was the impellant, Quebec had moved or been moved significantly away from dominance by the Bourget-Laflèche brand of ultramontanism. Clearly one of Wilfrid Laurier's most significant contributions to Canada was this achievement in divorcing a substantial number of his compatriots from the narrow identification of religious and political loyalty upheld by Bishop Laflèche.

Laurier did not accomplish this feat, however, without considerable negative help from Laflèche himself. Besides the extremity of the Laflèche statement which made it relatively easy for the Liberals to circumvent it, an important corollary to the mandement and election crisis concerns the deep differences between the bishop and other important pillars of the ultramontane movement. However logically the old prelate's way of thinking would seem to lead to a revival of "Le Programme Catholique" of the 1870's, Laflèche in his later years could see no practical alternative to a combination of support for, and pressure on, the existing Conservative party, Orange overtones notwithstanding. Here the "Castor-Rouge" alliance which formed the backbone of Honoré Mercier's Parti National after the Riel episode was the chief source of division. In Laflèche's mind, the name "Rouge" or "Libéral" could evoke only continental European revolutionaries, Papineau and the Dorion brothers, Freemasons, the Institut Canadien, and, very vivid in his consciousness, the forces which had led to the division of his diocese in 1885 . Even his journalist-disciples, Senator F.X. Trudel of L'Étendard and Jules Paul Tardivel of

33 PAC, Laurier Papers, Minehan to Laurier, July 6, 1896.

34 The Catholic Register, quoted in L'Electeur, May 29, 1896. 
$L a$ Vérité, came in for severe criticism from the man who had been very nearly their patron saint. Part of the Laflèche reaction may have been the result of the readiness of these ultramontane oracles, however devout, to lecture the clergy. But it was the Liberal danger which dominated the bishop's apprehensions. In a letter to Archbishop Taché shortly after the 1890 Manitoba move against the denominational schools, Laflèche spelled out his accusations against the Mercier formula and any attempt to repeat the "Castor-Rouge" combination on the federal level. Referring to the Dalton McCarthy crusade in Ontario on the Jesuit Estates' question, Laflèche saw only the splitting of Conservative elements in Quebec to the Liberals advantage :

Cette recrudescence de fanatisme et la formation du parti des equal rights, n'est que l'écho du parti national bas-Canadien qui est en train de mener notre province à la banqueroute, et de là à l'union législative d'Ottawa, ou à l'annexion aux États-Unis.

Nos nationaux de la Vérité et de l'Étendard, sont à mon humble avis, les hommes qui nous ont fait le plus de mal en jetant la division jusque dans les rangs du clergé, en soulevant les préjugés de race et de religion, et en se faisant les valets des libéraux. ${ }^{35}$

In both 1894 and 1895, Laflèche was instrumental in discouraging the movement for a French Catholic federal party aimed at bringing pressure on behalf of French and Catholic outside Quebec. Laflèche certainly approved the ultramontane composition of the French wing of the Cabinet which Sir Charles Tupper formed six weeks before the 1896 election, especially since it included his personal friend, Senator J. J. Ross. The rifts between himself and other ultramontanes such as Tardivel, however, were far from healed. It might be going too far to say that Laflèche split the ultramontane group; it must at least be maintained that he did not lend it the strong unifying thrust he might have given. Had there not been such a "division jusque dans les rangs du clergé," the ultramontane phenomenon might have assumed even more formidable proportions than it did.

Following the election, considerable episcopal re-grouping took place in self-defense against a mild but unmistakable reproof from the Vatican over the mandement. ${ }^{36}$ Tension mounted as delegations and counter-delegations travelled to Rome both before and after the Laurier-Greenway agreement of November, 1896. Recriminations against Laurier, perhaps more against Israel Tarte, at least temporarily covered over former differences of approach, notably those

35 AASB, Laflèche to Taché, May 19, 1890. July 8, 1896.

6 Archives Archiépiscopales de Montréal, Cardinal Ledockowski to Fabre, 
between Laflèche and Bégin. Not until the mission of Merry del Val and the Affari Vos letter of Leo XIII in late 1897 did a general spirit of moderation return. The crucial fact was, however, that moderation, even if grudging, did return. After the death of Laflèche in 1898, the tone and style of the Quebec church tended to be set by Bégin, who reverted to the Taschereau principle of avoiding unnecessary clashes, and by Paul Bruchési, the highly pragmatic successor to Archbishop Fabre at Montreal. There was some revival of the ultramontane thrust among the clerics who later supported Bourassa, as well as in the surviving Conservative party, but the "Castor-Rouge" phenomenon continued to prevent a coalescence of all ultramontanes into a single political camp.

If French Canadian nationalism had become ultramontane on its way to responsible government, ${ }^{37}$ it somewhat reversed the process on its way to the Laurier era. And, as dismayed as he might have been at the suggestion, Bishop Louis Laflèche, both by the extremity of his sermon against Laurier and by his refusal to canonize the ultramontane third party option, helped to speed the change.

37 See J. Monet, "French Canadian Nationalism and the Challenge of Ultramontanism," The Canadian Historical Association, Report (1966), pp. 41-55. 